Spelen met werkelijkheden 


\section{Spelen met werkelijkheden}

Systeemtheoretische psychotherapie met kinderen en jongeren

E. Reijmers

L. Cottijn

M. Faes (red.)

\$SS

Bohn Stafleu van Loghum

Houten 2005 
(C) 2005 Bohn Stafleu van Loghum, Houten

Alle rechten voorbehouden. Niets uit deze uitgave mag worden verveelvoudigd, opgeslagen in een geautomatiseerd gegevensbestand of openbaar gemaakt, in enige vorm of op enige wijze, hetzij elektronisch, mechanisch, door fotokopieën, opnamen, of op enige andere manier, zonder voorafgaande schriftelijke toestemming van de uitgever.

Voorzover het maken van kopieën uit deze uitgave is toegestaan op grond van artikel 16b Auteurswet $1912 \mathrm{j}^{\circ}$ het Besluit van 20 juni 1974, Stb. 351, zoals gewijzigd bij Besluit van 23 augustus 1985, Stb. 471 en artikel 17 Auteurswet 1912, dient men de daarvoor wettelijk verschuldigde vergoedingen te voldoen aan de Stichting Reprorecht (Postbus 3060, 2130 KB Hoofddorp). Voor het overnemen van (een) gedeelte(n) uit deze uitgave in bloemlezingen, readers en andere compilatiewerken (artikel 16 Auteurswet 1912) dient men zich tot de uitgever te wenden.

Eerste druk, 2005

ISBN 9031345776

NUR $777 / 848$

Ontwerp/vormgeving omslag en binnenwerk: designwork - bno, Deventer lilustratie omslag: Laura de Coninck

Bohn Stafleu van Loghum

Het Spoor 2

3990 GA Houten

www. bsl.nl

Belgiëlei 147a

2018 Antwerpen 
Voorwoord

Peter Adriaenssens

Inleiding: De oneerbiedigheid van het speelse

Ellen Reijmers

\section{SPELTALEN}

Ellen Reijmers a Lieve Cottyn

2 Speelse therapie

Over gestructureerd en vrij spel

Mieke Van Daele

$3 \quad$ Spelen met spel

Clara Vaes

4 Dramatechnieken als taaluitbreiding

Patsy Van Beek o Dany Baert

\section{REFLECTIES}

5 In therapie gaan

Over bezorgdheid en aarzelen

Peter Rober

6 Bespiegelingen

De zelfbeleving van kinderen

Mieke Faes

$7 \quad$ Lastige emoties

Last van last

Lieve Cottyn

\section{GEZINSVARIATIES}

Gebruik van settingwisselingen als therapeutisch instrument Nel Alblas 
$9 \quad$ Het landschap van de klacht

Narratieve hulpverlening aan kinderen

Paulien Kuipers a Jan Olthof

\section{PRAKTIJKMOZAÏEK}

10 Van slachtofferschap naar weerbaarheid

Lieve Coppens

11 De bewegende puzzel

Met kinderen spreken over psychosomatiek

Eric Vercruyssen

12 Gewoon ongewoon

Groepstherapie voor kinderen die op ongewone wijze in de wereld staan Mark Neyens

Literatuur

Personalia 
In een systeemtherapie kinderen actief betrekken, het lijkt wel of het alleen tijdens opleidingen in rollenspel beoefend wordt en verder enkel voor theoretische reflecties dient. Wie in de praktijk een systeemtherapeut zoekt die kinderen een plaats weet te geven als participant, komt met moeite hooguit op enkele namen in de regio. Er blijft een grote kloof bestaan tussen enerzijds de groeiende kennis over ontwikkelingspsychologie, het nut van preventie door kinderen vroeg te betrekken bij hulpverlening, de steeds duidelijker plaats zij in de samenleving krijgen, de vele opleidingen systeemtherapie en anderzijds de schaarse toepassing van deze kennis in de systemische praktijk.

De auteurs van dit boek hebben allen een ruime ervaring met kinderen in systeemtherapie. Eerder dan nog maar eens herschrijven van wat in veelvoud te vinden is, hebben zij de uitdaging aangenomen ook vanuit vele praktijkvoorbeelden te tonen hoe een systeemtheoretisch kader toegepast wordt.

Hoe kan een systeemtherapeut ervoor zorgen dat kinderen in een psychotherapie kunnen terugvinden wat hen het meest eigen is, zoals spel en humor? Hoe kunnen kinderen zich in de letterlijke zin van het woord door volwassenen uitgenodigd voelen om een eigen bijdrage te leveren aan de oplossing van de moeilijkheden? In dit boek wordt geïllustreerd hoe men creatief vordert dankzij het kind, terwijl zeer complexe, beangstigende, schijnbaar uitzichtloze problemen aangepakt worden. Het spel met werkelijkheid ontstaat als het kind voelt dat het duidelijk onderscheiden wordt van zijn klachten of probleem en als de therapeut taal geeft aan de relatie tussen het kind en het probleem, het kind en de omgeving. Daarbij voelt de ouder zich niet in de kou gezet, het probleem wordt er niet luchtiger door gemaakt, maar geplaatst binnen een verband, weg van een te beperkende pathologieomschrijving.

Wie dit boek leest mag iets ervaren wat niet zo vaak meegegeven wordt: het plezier, de vreugde van de systeemtheoretische psychotherapie. Een belangrijke, maar vaak onderschatte en miskende reden waarom vele systeemtherapeuten na enkele jaren hun enthousiasme achterlaten om zowel met ouders als kinderen te werken, is het verstikkende gevoel dat wie met kinderen werkt zich ieder moment bewust zou moeten zijn van de vele interacties in gezinnen, de relaties tussen gezin en buitenwereld, de kennis over ontwikkelingspsychologie en de vele therapiemodellen. Het gevolg is dat zij beginnen met splitsen en vereenvoudigen om uiteindelijk, onder de noemer van systemisch werken, ouders en kinderen volledig onafhankelijk van elkaar en van hun context te denken.

De auteurs in dit boek sturen aan op een attitude waarbij men zich in de sessies vrij genoeg voelt om inspiratie van het moment te benutten, de onverwachte inbreng van het kind toe te laten en te durven meegaan op diens sporen, daarbij erop vertrouwend dat het kind de partner is in het genereren van antwoorden. De therapeut die praat en denkt samen met het kind, brengt vanuit de eigen verbeelding taal en verhalen aan, die nieuwe bruggen kunnen leggen voor het verhaal waarin het kind gevat zit. De auteurs tonen met heel wat voorbeelden hoe het kind ineens een nieuwe opening of ander perspectief ontdekt door de speelse 
wijze waarop de psychotherapeut taal hanteert. Het speelse geeft een aanvullende dimensie doordat werkelijkheid en fantasie elkaar kunnen inspireren. Het spontane, het zomaar zeggen en doen of een verrassende beeldspraak, worden minder gezien als "sleutels waarvan wij moeten doorgronden wat de diepere betekenis kan zijn", maar meer aanvaard als deel van het therapeutisch proces.

De therapeut die bezwaard is door ernst wordt opgeslokt door een innerlijke dialoog die de verbinding met het kind en zijn omgeving verstoort. Met een speelse attitude werpen de auteurs het badwater van de kennis niet weg. De praktijk en theorie blijven in alle bijdragen intens verbonden. Zij bieden een verruiming van het bestaande, wat voor kinderen en hun gezinnen een verrijking is.

Dit boek onderlijnt volgens mij een belangrijk spoor. Kinderen als actieve participanten houden namelijk ook heel wat kansen voor ouders in. In het verhaal van het kind (h)erkennen ouders eigen kwetsuren, transgenerationele verhalen, wensen, verlangens en contextgebonden beperkingen. Ouders worden geïnspireerd door de nieuwe wegen die het kind voor zichzelf vindt en kunnen besluiten om hetzelfde medicijn ook voor zichzelf voor te schrijven. Problemen in de communicatie tussen ouders en kind verbeteren niet alleen door te praten over het probleem, maar ook omdat het kind nu ondervindt dat de eigen unieke manier waarop het zich uitdrukt gerespecteerd wordt en aandacht krijgt.

De auteurs hebben niet de pretentie een wonderkuur voor te stellen. Ze zijn er zelf voldoende alert op om geen pleidooi te houden om bestaande dominante modellen te vervangen door een ander, even dominant model. Therapeutische effecten hebben eerder te maken met het verminderen van de impact van problemen, doordat ouders en kind zelf de overgang hebben kunnen maken door meer bezig te zijn met (hun) relaties dan met het probleem zelf. Zo komt een meer leefbare werkelijkheid voor alle betrokkenen dichterbij.

In een boek dat dermate over spel, speelse werkelijkheden en fantasie gaat, zal het niet verrassen dat je vaak leest alsof je de auteur verhalend aan het woord hoort. Vertel, vertel het voort.

Peter Adriaenssens

Kliniekhoofd Kinderpsychiatrie

Universitaire Ziekenhuizen Leuven 